\title{
Taxonomic record and distribution pattern of the freshwater apple snail, Pila glo- bosa (Swainson, 1822) (Mesogastropoda : Pilidae)
}

\author{
B. K. Saha ${ }^{1}$, M. Sarwar Jahan and M. A. Hossain
}

Fisheries Research Laboratory, Department of Zoology, University of Rajshahi, Rajshahi-6205, Bangladesh

\begin{abstract}
A study was carried out on taxonomic record and distribution pattern of the freshwater apple snail, Pila glogosa from January 1995 to December 1996 in different waterbodies of Rajshahi University Campus. In total, 27 generic and 21 species names were recorded including the valid name Pila globosa (Swaindon, 1822). The shell of $P$. gloosa is thick and globose. The spire is not acuminate and shorter than the body whorl. The apple snail was found to occur in tanks, ponds, ditches and irrigated paddy fields of Rajshahi University Campus, Rajshahi. The apple snail prefered littoral zones of ponds and ditches but shore lines of canals and irrigated paddy fields. Aestivation of the apple snsails took place with the total water loss of the habitats.
\end{abstract}

Keywords : Taxonomic recorde; Distribution; Pila globosa; Synonymy; Shell

\section{Introduction}

Freshwater gastropods, which constitute the bulk of littoral fauna of tanks, ponds, beels, reservoir and rivers, play an important role in the dynamics of aquatic ecosystems. Sufficient works have been done in abroad on population dynamics, growth, reproduction, life cycle and bioenergetics of a number of gastropods (DeWitt, 1955; Duncan, 1959; Gillespie, 1969; Eckblad, 1973 and Browne, 1978). The genus Pila is confined in the Oriental and Ethiopian regions (Preston, 1915).

But in Bangladesh, there is a general lack of detailed information on any gastropod species. Ali and Chakraborty (1992) and Jahan (1993) mentioned the taxonomic record, distribution and some ecological notes of a few gastropods found in the country. Therefore, a study was conducted to note the taxonomic record and distribution pattern of $P$. globosa from Rajshahi University Campus.

\section{Material and methods}

Surveys were conducted at fortnight intervals throughout the tenure (January 1995 to December 1996) based on the observations and sampling in selected managed fish ponds, ditches and irrigated paddy fields in the Rajshahi University Campus (Fig.1) to find out distribution pattern of Pila globosa.

\footnotetext{
*Corresponding author. e-mail: bimalkantasaha@yahoo.com
}

\section{Collection}

Random sampling of P. globosa was done twice a month (on the first and the 15th day) from the ponds, ditches and irrigated paddy fields of Rajshahi University Campus in the morning. A total of 1,324 specimens was collected during the tenure of which 1,175 specimens were found suitable in all respects. The snails were collected with the help of cast nets, small hand nets and hand-picking methods.

\section{Results and discussion}

1. Taxonomic record

1.1 Identity

Valid name: Pila globosa (Swainson, 1822)

1.2 Synonymy

\section{Generic names}

1797 Pomus, Mus. Calonnianum, p.58.

1798 Pila (Bolten) Roeding, Mus. Boltenianum, p.145 ( in part ).

1799 Ampullaria (in part), Lamarck, Prodrome, p. 76.

1817 Conchylium (in part), Cuvier, Regne Anim, II,p. 426.

1821 Ampullaria, Sowerby, Genera 1, pl. el. XXXIV.

1828 Pachystoma, Guilding, Zool. J.III, p.536.

1840 Pachylabra, Swainson, Malacologia, p.339.

1847 Pomus, Gray, Proc. zool. Soc. London, p.148.

1854 Ampullaria, H. \& A. Adams, Gen. Rec. Moll. 1, p.345.

1859 Ampullaria, Chenu, Man. Conchyl., p.313. 
1883 Amullaria, Tryon, Struct. and Syst. Conch. II, p.276.

1885 Pachylabra, Fischer, Man. Conchol., p.757.

1904 Pila, Dall, Journ. Conchol. xi., p.53.

1910 Pila (subgenus), Sowerby, Proc. malac. Soc. Lond. IX, p.56.

1912 Pachylabra, Kobelt, Martini \& Chenn., Conch. Cub.(n.f.) Ampullariidae, p.44.

1915 Pila, Preston, Faun.. Brit. Ind. Freshw. Moll., p.96.

1921 Pachylabra, Annandale \& Prashad, Rec. Indian Mus., XXII, p.47.

1932 Pila, Prashad, Indian Zool. Mem.4, p.1.

1964 Pila, Meenakshi, Comp. Biochem. Physiol.11, p.379.

1964 Pila, Brahmachary, Experimentia, p.133.

1967 Pila, Hyman, The Invertebrates, vi, Mollusca, p.223.

1976 Pila, Brahmanandan,Veliger, 19(1), p.90.

1989 Pila, Subba Rao, Handbook: Freshw. Moll. India, p.57.

\section{Species names}

1822 A. globosa, Swainson, Zool. Illustrations ser.I,II, pl.eXIX, III, pl.eXX.

1851 A. globosa, Philippi in Martini \& Chenn., Conch. Cab. Ampullaria, p.8, pl.1, fig.3; p.7, pl.i, fig.1.

1856 A. globosa, Reeve, Conch. Icon.X, Ampullaria, pl.X, figs.46,47; pl.XVI, fig.76.

1876 A. globosa (nec Lamarck), Hanley \& Theobold, Conch. Ind., pp.XVII,46, pl.eXIII, figs.2-5.

1877 A. globosa, Nevill, Cat. Moll. Indian Mus., Fasc. E., pp.1,2.

1885 A. globosa, Nevill, Hand-list Moll. Indian Mus.II, pp. 1-2.

1910 A. (Pila) globosa,.Sowerby, Proc.malac. Soc. Lond.IX, pp.58-59.

1912 A. globosa, Ghose, Rec. Indian Mus., 7, p.77.

1912 A. globosa, Kobelt in Martini \& Chenn., Conch. Cab.(n.f.) Ampullariidae, p.72,pl. XXIV, figs.1-2; p.95, pl.XLI, fig.1.

1915 P. globosa, Preston, Faun. Brit. India, Freshw. Moll., pp.97-98.

1923 P. globosa, Prashad, J. As. Soc.Bengal(n.s.) XVII, p.586.

Different authors such as Srivastava Rao (1929), Raja (1945), Lal and Saxena (1952), George and Desai (1955),
Raghupathiramireddy and Swami (1968), Ganapati and Hanumantha Rao (1968), Reddy et al. (1974), Mohan et al. (1975), Munnis (1978), Raut (1984), Ali and Chakraborty (1992) and Jahan (1993) used the name P. globosa.

Systematic position

$\begin{array}{ll}\text { Kingdom } & \text { Animalia } \\ \text { Phylum } & \text { Mollusca } \\ \text { Subphylum } & \text { Conchifera } \\ \text { Class } & \text { Gastropoda } \\ \text { Subclass } & \text { Prosobranchia } \\ \text { Order } & \text { Mesogastropoda } \\ \text { Family } & \text { Pilidae } \\ \text { Subfamily } & \text { Pilinae } \\ \text { Genus } & \text { Pila } \\ \text { Species } & \text { P. globosa }\end{array}$

Diagnostic characters

The shell of Pila globosa is thick and globose. The body whorl is highly convex in profile. The aperture is wide, smooth and oblong. The spire is shorter than the body whorl and not acuminate. Columella is in the shape of a hollow twisted rod. Operculum is a flat oblong plate-like structure. The outer flat surface of it shows many concentric rings of growth around a small subcentric circle, the nucleus. The inner surface is a distinct elliptical area of creamy colour. It is surrounded by a shallow groove. The colouration varies greatly and it is always dull.The ground colour is lemon-yellow, brownish or even blackish. The inner surface of the shell is pinkish (Fig. 2).

\section{Distribution}

Pila globosa was found to occur in tanks, ponds, ditches, canals and irrigatedpaddy fields of Rajshahi University Campus, Rajshahi. This snail prefered littoral zones of ponds and ditches but shorelines of canals and irrigated paddy fields. These snails prefered soft or clayey substratum instead of sandy one. In the dry season, i.e., with the advancement of fall of water level in the temporary waterbodies (ditch, canal, paddy field), the snails started to 


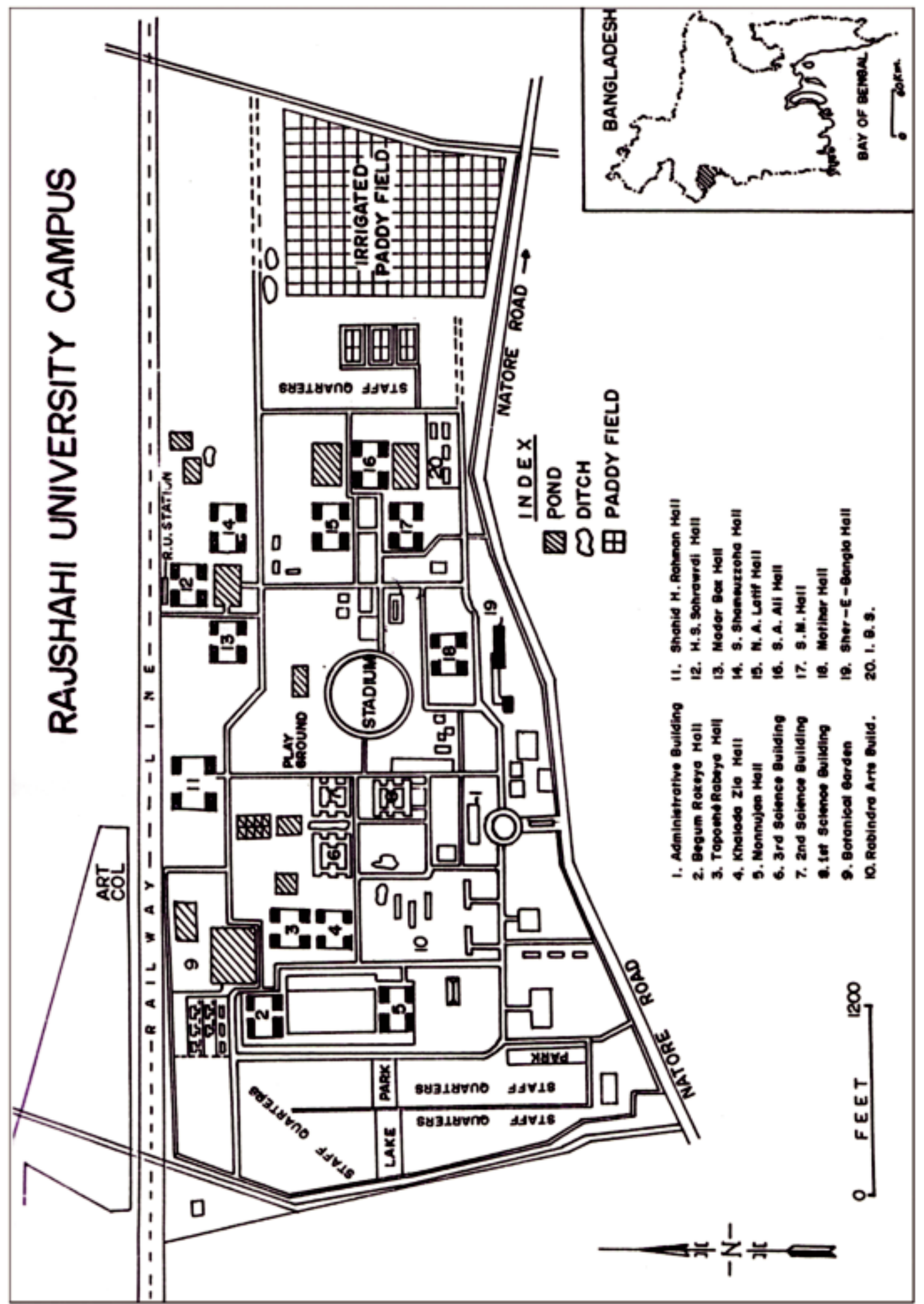

Fig. 1. Rajshahi University Campus showing sampling stations. 
was performed completely with the total waterloss of the habitats. Saxena (1956) observed P. globosa to occur usually near the banks of the lakes and sometimes encountered a few snails in the deeper waters during aestivation period. A study by Raut (1984) was made to observe the distribution of $P$. globosa which suggests that this amphibious prosobranch usually occured in large numbers in the paddy fields during monsoon and in the ponds throughout the year.

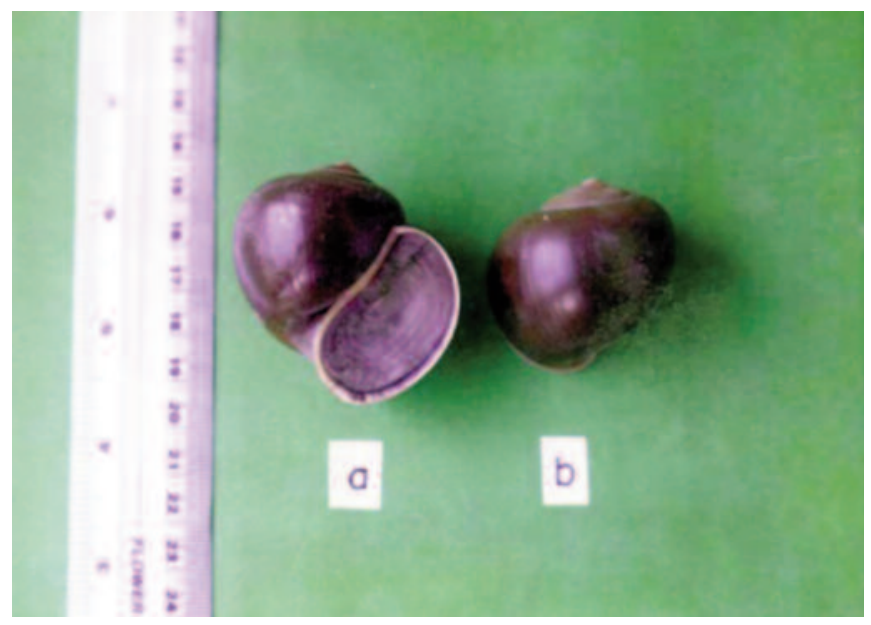

Fig. 2. Apertural (a) and abapertural (b) views of Pila globosa.

\section{Conclusion}

Pila globosa is an edible mollusc and its flesh is highly proteineous. In the recent past, it was abundant in our stagnant waterbodies but it is declining rapidly. The information obtained in the present investigation may be useful for taxonomy of molluscan fauna and may be helpful for proper management, development and conservation strategy to restore this edible snail.

\section{References}

Ali S and Chakraborty T (1992), Bangladesh Mitha Panir Amerudandi Prani (A book on Freshwater Invertebrates of Bangladesh). Bangla Academy, Dhaka, Bangladesh, Ist Ed., p. 208..

Browne AR (1978), Growth, mortality, fecundity, biomass and productivity of lake populations of the prosobranch snail, Viviparus georgianus, Ecology, 59: 742756.
DeWitt RM (1955), The ecology and life history of the pond snail, Physa gyrina, Ecology, 36: 40-44.

Duncan CJ (1959), The life cycle and ecology of a freshwater snail, Physa fontinalis, J. Anim. Ecol. 28: 97-117.

Eckblad JW (1973), Population studies of three aquatic gastropods in an intermittent brackishwater, Hydrobiologia, 41: 199-219.

Ganapati PN and Rao KH (1968), On anomalous emission of echinostome larval stages and the intraredial encystment of cercariae in the snail, Pila globosa (Swainson), Curr. Sci. 37: 19-20.

George JC and Desai BN (1955), On the liver fat in Pila globosa (Swainson), J. Anim. Morph. Physiol. 1: 56-58.

Gillespie DM (1969), Population studies of four species of molluscs in the Madison river.Yellowstone National Park, Limnol. Oceanogr. 14: 101-114.

Jahan MS (1993), Some terrestrial and freshwater gastropods of Bangldesh with their ecological notes, Univ. J. Zool. Rajshahi Univ. 12: 65-71.

Lal MB and Saxena BB (1952), Urecotelish in Pila globosa (Swainson), Nature 170: 95.

Mohan PM, Reddy AV and Babu KS (1975), Diurnal variation in acetyl-cholinesterase activity in the nervous system of the aestivating snail, Pila globosa, Curr. Sci. 44(10): 347.

Munnis N (1978), Neurochemical correlates of aestivation, Amnintransferase heterogenicity in the cerebral ganglion of the amphibious snail, Pila globosa, Proc. Indian Acad. Sci. Sect. 85(5): 278-282.

Preston HB (1915), The fauna of British India including Ceylon and Burma : Mollusca (Freshwater Gastropoda and Pelecypoda ), Taylor and Francis, London, pp. 1244.

Raghupathiramireddy S and Swami KS (1968), The occurrence of helicorubin in the Indian Apple snail, Pila globosa, Archs. Int. Physiol. Biochem. 76: 26-36.

Raja SN (1945), A preliminary account of the development and disintegration of the shell and gland in Pila globosa, Proc. Indian Sci. Congr. 29(3): 154. 
Raut SK (1984), On the egg laying behaviour of the apple snail, Pila globosa (Swainson) (Mollusca: Gastropoda), Sci. Cult. 50(6): 198-199.

Reddy YS, Rao PV and Swami KS (1974), Probable significance of urea and uric accumulation during aestivation in the gastrood, Pila globosa (Swainson), Indian J. Exp. Biol. 12(5): 454-456.

Saxena BB (1956), Some observations on the ecology and behaviour of the common Indian apple snail, Pila globosa (Swainson), J. Bombay Nat. Hist. Soc. 53: 733736.
Srivastava RH (1929), The freshwater and amphious gastropod molluscs of the Indwgyi lake and of the connected freshwater areas in the Myitkyina district, Burma, Rec. Indian Mus. 31: 274-279.

Received: 23 November 2015; Revised:21 February 2016; Accepted: 24 April 2016. 